\title{
Do Perceptions About Local Environmental Quality Influence Self-Rated Health? Evidence from Ghana
}

\author{
Iddisah Sulemana (Corresponding author) \\ GIMPA Business School, Ghana Institute of Management \& Public Administration \\ P. O. Box AH 50, Achimota, Accra, Ghana
}

Tel: 233-501-214-414Ｅ-mail: is6d9@mail.missouri.edu

Received: October 15, 2016 Accepted: November 16, 2016

doi:10.5296/emsd.v5i2.10156 URL: http://dx.doi.org/10.5296/emsd.v5i2.10156

\begin{abstract}
Although climate change and other global environmental problems are of top priority among world leaders (especially for those of developed countries), local environmental problems continue to bedevil people in developing countries like Ghana. In these countries, people continue to battle with poor air quality, poor water quality and poor sewage and sanitation. The purpose of this study is to examine the association between perceived local environmental quality and self-rated health among Ghanaians. Empirical results from ordered probit regressions based on data from the Wave 5 of the World Values Survey reveal a negative association between environmental quality and self-rated health. This study contributes to the literature on the relationship between environmental quality and health by adding further empirical evidence from a developing country perspective.
\end{abstract}

Keywords: Environmental quality, Perceived local environmental quality, Perceived health status, Self-Rated health, Ghana

JEL Codes: I100 I120 Q530

\section{Introduction}

The World Health Organization (2015) reported in its World Malaria Report 2015 that about 214 million malaria cases were recorded globally in 2014. Furthermore, there were about 438,000 malaria deaths globally since 2000 . The report further indicated that the majority of these cases and deaths occurred in Africa. Specifically, 90\% of the malaria deaths since year 2000 were in Africa. In Ghana, the Ghana Health Service (2015) reported that about 8.4 million cases of malaria were recorded in 2014 compared to 11.4 million cases in 2013 . Although this constitutes a decline of about $23.6 \%$ in malaria cases, the number of cases recorded is still very high in the country (Ghana Health Service, 2015). 
Thus, although climate change and other global environmental problems are of top priority among world leaders (especially for those of developed countries), local environmental problems continue to bedevil people in developing countries such as Ghana. In these countries, people continue to battle with poor air quality, poor water quality and poor sewage and sanitation. These local environmental problems have deleterious consequences for human health and wellbeing. For instance, poor water quality and poor sewage and sanitation may cause water-borne and other diseases such as malaria, cholera, giardiasis, and cryptosporidiosis (e.g., Gadgil, 1998; Mouchet et al., 1998; Githeko \& Woodward, 2003) while poor air quality may result in chronic or fatal respiratory problems and mortality especially through declines in lung function (e.g., Pope III et al., 1995; KuÈnzli et al., 2000; Ravindra et al., 2001). Accordingly, world leaders and policymakers also concern themselves with improving public health. In particular, three of the Millenium Development Goals (MDGs) pertain to health (see e.g., Drabo, 2011). Health is particularly important for developing countries because it is part and parcel of human capital, which is direly needed to fuel economic growth and development in these countries (e.g., Drabo, 2011). ${ }^{1}$

There is substantial literature on the relationship between objective measures of environmental pollution and objective health (e.g., Pope III \& Dockery, 1992; Bruce et al., 2000; Fawell \& Nieuwenhuijsen, 2003; Neidell, 2004; Kampa \& Castanas, 2008). On the other hand, the body of research on whether subjective measures of environmental pollution or quality are correlated with self-rated health is sparse but growing (e.g., Kahlmeier, et al., 2001; Poortinga et al., 2007). Perceived air quality may influence self-rated health (e.g., Kahlmeier, et al., 2001). Among other predictors of self-rated health (e.g., poor access to amenities, neighborhood disorder, lack of social cohesion, etc.), Poortinga et al. (2007) found that poor neighborhood quality significantly influences self-rated health in the UK.

Studies show that self-rated health is an important predictor of mortality (Mossey \& Shapiro, 1982; Idler \& Benyamini, 1997; Heistaro et al., 2001; DeSalvo et al., 2006). Based on longitudinal survey data from Manitoba in Canada, Mossey \& Shapiro (1982) observed that self-rated health significantly influences mortality among the elderly and that this effect is independent of objective health status. In this paper, I examine the association between perceived local environmental quality and self-rated health (i.e., perceived health status) among Ghanaians. I consider three local environmental quality measures - poor air quality, poor water quality, and poor sewage and sanitation. Empirical results from ordered probit regressions based on data from the Wave 5 of the World Values Survey reveal a negative association between each environmental quality issue and self-rated health.

This paper is motivated by the argument that studies on the effect of environmental quality on health could inform policy choices that could improve the general health of people (e.g., Drabo, 2011). Additionally, research shows that self-rated health is a good predictor of health

\footnotetext{
1 Traditionally, scholars have argued that economic growth engenders environmental degradation. Most studies examining this relationship have done so within the Environmental Kuznets Curve framework (see e.g., Grossman \& Krueger, 1991; Shafik \& Bandyopadhyay, 1992; Stern, 2004; Andreoni \& Levinson, 2001; Sulemana et al., 2016c). However, a growing number of studies now argue that environmental degradation (especially through higher $\mathrm{CO}_{2}$ emissions) could undermine economic growth especially in developing countries (see e.g., Azam, 2016; Azam et al., 2016).
} 
care utilization (Fernandez-de-la-Hoz \& León, 1996). Because perceived (subjective) measures of environmental quality may actually exert more effect on health than objective measures (Ross \& Mirowsky, 2001; Wu et al., 2013), examining whether perceived local environmental problems affect self-rated health is not an exercise in futility. Accordingly, this study seeks to contribute to the literature by adding empirical findings to the environment-health research. Furthermore, most studies on this topic are often developed-country focused. This study provides a developing country perspective on the debate. Finally, to the best of my knowledge, this is the first study to examine the association between perceived environmental quality and self-rated health in Ghana.

\section{Literature Review}

That self-rated health is an important predictor of actual health outcomes is well documented. For instance, Mossey \& Shapiro (1982) showed that the odds of mortality among people indicating poor health is about three times greater relative to those who indicated good health (p. 803). They further noted that among the predictors of mortality they examined (e.g., objective health status, age, gender, and residential location), self-rated health was the second most powerful predictor of mortality (age being the first). This suggests that self-rated health may actually have more effect on mortality than do objective health status (e.g., Ross \& Mirowsky, 2001; Wu et al., 2013).

The effect of neighborhood characteristics (including neighborhood quality) on individual health outcomes has been studied (e.g., Cummins et al., 2005; Poortinga et al., 2007; Nielsen \& Hansen, 2007; Mitchell \& Popham, 2008; Do \& Finch, 2008; Collins et al., 2009; Stronegger et al., 2010). Stronegger et al. (2010) explored the relationships among perceived neighborhood quality, physical activity and self-rated health for residents of the Austrian city of Graz and observed that those who reported high residential quality also tended to indicate high, positive ratings of their health. Living in "green" neighborhoods also has a positive influence on self-rated health (Nielsen \& Hansen, 2007; Mitchell \& Popham, 2008). Nielsen and Hansen (2007) observed that access to green areas or a garden is correlated with lower experienced stress and reduced likelihood of obesity based on a survey of about 1200 Danes aged between 18 and 80 .

A study of English population below retirement age revealed that health inequalities are lower among people exposed to the "greenest environments" after controlling for income-deprivation (Mitchell \& Popham, 2008, p. 1655). In another study based on data from Scotland and England, Cummins et al. (2005) examined the relationship between neighborhood environment and self-rated health. Their results revealed that poor physical quality residential environment was significantly correlated with fair to very bad health status. Using a large dataset of almost 100,000 respondents from the Korean Community Health Survey (KCHS), Lee et al. (2015) investigated the effect of social and physical environments on self-rated health among rural and urban residents in Korea. After controlling for other covariates of self-rated health, they found that favorable social environmental factors were positively associated with self-rated health for both rural and urban residents. These factors included phenomena such as whether the respondent trusted their neighbors, whether they 
exchanged help, fellowshipped together, spent leisure time together, etc. Additionally, positive physical environmental factors such as feeling safe in one's neighborhood, traffic and natural living conditions were all positively correlated with self-rated health.

A greater proportion of the over 2.5 billion people who lacked access to improved sanitation in 2012 were resident in Africa (United Nations, 2014). In Ghana, like many developing countries, open urination or defecation, misguided littering and dumping of refuse into gutters or even water bodies, etc. are not uncommon especially in rural areas. These and other acts pollute the water bodies, and because some residents lack access to treated water and have to obtain drinking water directly from these sources (e.g., Tayeh et al., 1993; Shier et al., 1996), such individuals may be exposed to water-borne diseases such as malaria, cholera, giardiasis, and cryptosporidiosis thereby hurting their health (e.g., Gadgil, 1998; Mouchet et al., 1998; Githeko and Woodward, 2003). The United Nations (2014) reported that 768 million had no access to safe-drinking water in 2011. Furthermore, air pollution from vehicular emissions is common, especially in the cities (e.g., Armah et al., 2010; Sulemana, 2012). These emissions have negative effects on human health (Carreras \& Pignata, 2002; Affum et al., 2008; Armah et al., 2010).

Knowledge of these dynamics may lead individuals who perceive their local communities to have environmental problems to rate their health accordingly (independent of their objective health status). Explaining why self-rated health affects mortality, Mossey and Shapiro (1982) noted that an individual may maintain positive health habits like moderate alcohol consumption, non-smoking behavior or physical exercise that leads them to have a positive rating of their own health. Therefore, a similar argument could be made about the relationship between perceived local environmental quality and self-rated health.

\section{Data and Empirical Strategy}

To examine the association between perceived local environmental quality and self-rated health, this paper draws on data from the Wave 5 of the World Values Survey conducted in many countries across the globe. In Ghana, the survey was conducted from February to April 2007. Using probability sampling, the investigators ensured that the households selected were a nationally representative sample. About 1500 individuals were interviewed in face-to-face encounters in five Ghanaian languages, namely, Ga, Dagbani, Ewe, Twi and Hausa. Among other variables, the survey contained questions on environmental quality and health of respondents that allow for statistical analysis.

The dependent variable is the individual's health status based on their own (subjective) evaluation of their overall state of health. Respondents were presented with the following question:

All in all, how would you describe your state of health these days? Would you say it is:

$$
\begin{aligned}
& 1=\text { Very good } \\
& 2=\text { Good } \\
& 3=\text { Fair } \\
& 4=\text { Poor. }
\end{aligned}
$$


This is a typical question used in measuring self-rated health in the literature.

With regards to the explanatory variable (i.e., environmental quality), the survey contained questions soliciting respondents' views on various environmental problems in "the world as a whole" and in the individuals "own community." Here, I focus on the latter. The question was presented as follows:

I am going to read out a list of environmental problems facing many communities. Please, tell me how serious you consider each one to be here in your own community. Is it very serious, somewhat serious, not very serious or not serious at all? [1= Very serious; 2 = Somewhat serious; $3=$ Not very serious; $4=$ Not at all serious]

- Poor air quality

- Poor water quality

- Poor sewage and sanitation

If indeed neighborhood characteristics or quality can be captured by people's subjective assessment of their neighborhood (e.g., Cho et al., 2005), then one can argue that people's assessment of the seriousness or otherwise of environmental problems in their community may fairly reflect the actual seriousness or otherwise of those environmental problems in those communities. Furthermore, because the survey instrument enquires about the seriousness of the environmental problem in the respondent's "own community," I follow the precedent of previous studies (e.g., Sulemana et al., 2016a; Sulemana et al., 2016b) and refer to these problems as "local environmental problems." Accordingly, I create three separate measures of local environmental quality based on the issues above, respectively - poor air quality, poor water quality and poor sewage and sanitation.

I include as control variables the following socio-demographic factors: age, gender, education, employment status, marital status, and size of town of residence. It seems that older usually report poor self-rated health than younger people (e.g., McCullough \& Laurenceau, 2004). This is particularly true for people above 50 years (McCullough \& Laurenceau, 2004). The literature suggests that females mostly tend to report lower self-rated health compared to their male counterparts (e.g., Rahman et al., 1994; McCullough \& Laurenceau, 2004), although some studies do not find evidence to support this (e.g., Benyamini et al., 2003). Rahman et al. (1994) observed that across the United States, Jamaica, Malaysia and Bangledish, women were more likely to report poor health status than men. Higher educational attainments may be positively associated with self-rated health (e.g., Ross \& Wu, 1996; Hill \& Needham, 2006) while lower educational attainments are correlated with poor self-rated health (e.g., Mulsant et al., 1997).

Also, unemployed people are found to report poor self-rated health (e.g., Giatti et al., 2011; Carlier et al., 2013; Norström et al., 2014) and this finding may hold irrespective of whether personal or contextual characteristics are controlled for (Giatti et al., 2011). The literature also shows that income is associated with self-rated health (e.g., Kennedy et al., 1998; Shibuya et al., 2002; Addai \& Adjei, 2014). I control for income by using the income proxy 
"income scale." Marital status also affects self-rated health. Specifically, marital dissolution (divorce or separation and widowhood) usually undermines self-rated health (Joutsenniemi et al., 2006; Liu, 2012). Yet some studies do not find a significant effect of marital status on self-rated health (Kawada \& Suzuki, 2011; Addai \& Adjei, 2014). Finally, the respondent's size of town of residence may influence an individual self-rated health due to differences in access to health facilities in rural versus urban areas. In Ghana, urban areas typically have more health amenities than their rural counterparts. Thus, rural residents may report poorer self-rated health than their urban counterparts (e.g., Monnat \& Pickett, 2011; Bethea et al., 2012).

To empirically estimate the influence of perceptions about local environmental quality on self-rated health, I employ the following econometric model:

$$
S R H_{i}=\alpha+\beta * P L E Q_{i}+\gamma * \sum_{i=1}^{n} \operatorname{CONTROLS}_{i}+\varepsilon_{i}
$$

In this model, SHR denotes self-rated health, PLEQ refers to perceived local environmental quality while CONTROLS are the socio-demographic characteristics that could influence self-rated health as discussed above. $\alpha$ is the intercept, $\beta$ and $\gamma$ are vectors of parameters to be estimated while $\varepsilon$ is the idiosyncratic error term. The "i" indexes the individual respondent. Because the dependent variable (self-rated health) is ordinal, an ideal estimation technique is ordered probit (see e.g., McKelvey \& Zavoina, 1975; Becker \& Kennedy, 1992). Consequently, equation (1) is estimated using ordered probit.

\section{Results and Discussion}

Table 1 presents the descriptions along with summary statistics of the variables used in the study. The ages of the respondents ranged from 16 to 90 with a mean age of 34 years and about half of them were female. The majority of respondents $(60.2 \%)$ either had primary education or no formal education, $34.3 \%$ had secondary education while $5.5 \%$ had attained university education. About $22.8 \%$ were unemployed. The average income scale was 4.453 suggesting that the majority of respondents perceived their household income to be within the lower half of the income scale. At the time of the survey, about $50.6 \%$ of respondents were married, $5.6 \%$ were either divorced or separated, while $43.7 \%$ were either single or widowed. Regarding the size of town of residence, about $56.4 \%$ of respondents lived in a town with less than 10,000 people, $19.1 \%$ lived in a town with between 10,000 and 100,000 people while $24.5 \%$ of them lived in a town of more than 100,000 people.

\footnotetext{
${ }^{2}$ Ideally, this income variable should be an actual estimate of the individual's income (especially annual) or their household income. However, the survey did not ask for household income. Instead, respondents were asked to indicate what income decile their household belonged to (1=lowest income decile and 10=highest income decile). As a precedent, Addai \& Adjei (2014) used income scale in lieu of income in their examination of the predictors of self-rated health in Ghana.
} 
Table. 1. Variable descriptions and summary statistics

\begin{tabular}{|c|c|c|c|c|}
\hline Variable & Description & Mean & S. D. & Range \\
\hline Self-rated health & $\begin{array}{l}\text { A measure of self-rated health based on the question "All in } \\
\text { all, how would you describe your state of health these days?" } \\
(1=\text { Very good; } 2 \text { = Good; } 3 \text { = Fair; } 4=\text { Poor })\end{array}$ & 3.119 & 0.864 & $1-4$ \\
\hline Poor water quality & $\begin{array}{l}\text { A measure of the respondent's perception of the seriousness } \\
\text { or otherwise of poor water quality in their own community } \\
(1=\text { Very serious; } 2 \text { = Somewhat serious; } 3=\text { Not very } \\
\text { serious; } 4 \text { = Not at all serious) }\end{array}$ & 3.264 & 0.954 & $1-4$ \\
\hline Poor air quality & $\begin{array}{l}\text { A measure of the respondent's perception of the seriousness } \\
\text { or otherwise of poor air quality in their own community (1= } \\
\text { Very serious; } 2=\text { Somewhat serious; } 3=\text { Not very serious; } 4 \\
\text { = Not at all serious) }\end{array}$ & 2.800 & 1.080 & $1-4$ \\
\hline $\begin{array}{l}\text { Poor sewer and } \\
\text { sanitation }\end{array}$ & $\begin{array}{l}\text { A measure of the respondent's perception of the seriousness } \\
\text { or otherwise of poor sewage and sanitation in their own } \\
\text { community ( } 1=\text { Very serious; } 2=\text { Somewhat serious; } 3=\text { Not } \\
\text { very serious; } 4=\text { Not at all serious) }\end{array}$ & 1.713 & 0.927 & $1-4$ \\
\hline Age & Age of respondent (in years) & 33.895 & 13.923 & $16-90$ \\
\hline Female & Unity if gender is female; zero otherwise & 0.497 & 0.500 & $0-1$ \\
\hline Primary or less & $\begin{array}{l}\text { Unity if respondent's highest level of education attained is } \\
\text { primary or had no formal education; zero otherwise }\end{array}$ & 0.602 & 0.490 & $0-1$ \\
\hline Secondary & $\begin{array}{l}\text { Unity if respondent's highest level of education attained is } \\
\text { secondary education; zero otherwise }\end{array}$ & 0.343 & 0.475 & $0-1$ \\
\hline University & $\begin{array}{l}\text { Unity if respondent's highest level of education attained is } \\
\text { university education; zero otherwise }\end{array}$ & 0.055 & 0.229 & $0-1$ \\
\hline Unemployed & Unity if respondent was unemployed; zero otherwise & 0.228 & 0.419 & $0-1$ \\
\hline Income scale & $\begin{array}{l}\text { Variable indicating what income decile the respondent } \\
\text { believes their household is (1=lowest income decile and } \\
10=\text { highest income decile" }\end{array}$ & 4.453 & 2.304 & $1-10$ \\
\hline Married & Unity if married or living together as married; zero otherwise & 0.506 & 0.500 & $0-1$ \\
\hline Divorced/separated & Unity if divorced or separated; zero otherwise & 0.056 & 0.230 & $0-1$ \\
\hline Other marital status & Unity if widowed, or single/never married; zero otherwise & 0.437 & 0.496 & $0-1$ \\
\hline Small town & Unity if size of town is 10,000 or less; zero otherwise & 0.564 & 0.496 & $0-1$ \\
\hline Mid-size town & $\begin{array}{l}\text { Unity if size of town is between } 10,000 \text { and } 100,000 \text {; zero } \\
\text { otherwise }\end{array}$ & 0.191 & 0.393 & $0-1$ \\
\hline Large town & Unity if size of town is over 100,000 ; zero otherwise & 0.245 & 0.430 & $0-1$ \\
\hline
\end{tabular}

The mean score for self-rated health of 3.119 lies between fair $(=3)$ and poor $(=4)$. For each of the 3 environmental problems, it seems that the majority respondents considered each problem as somewhat serious or very serious. Detailed distributions of the responses to the health and environmental problems questions are reported on Table 2. When asked about their health, $37.2 \%$ and $43.1 \%$ indicated "very good" and "good", respectively, compared to $13.6 \%$ for "fair" and $6.1 \%$ for "poor." Thus, most respondents had positive appraisal of their health. 
With respect to the poor environmental quality questions, the proportion of respondents indicating either "very serious" and "somewhat serious" is relatively far larger for poor water and poor sewage and sanitation problems than those indicating "not very serious" or "not at all serious." While only 5.5\% and 8.4\% indicated "not at all serious" and "not very serious" to the state of poor water quality in their own community, about $19.9 \%$ and $51.6 \%$ reported that poor water quality was "somewhat serious" and "very serious" respectively in their community. This pattern is identical for the distribution of the responses to the poor sewage and sanitation question. On poor air quality, the distribution of the responses was $36.7 \%$ (very serious), $20.4 \%$ (somewhat serious), $29.4 \%$ (not very serious) and $12.9 \%$ (not at all serious).

Table. 2. Distribution of responses to health and environmental quality questions

\begin{tabular}{|l|l|l|l|l|}
\hline & \multicolumn{4}{|c|}{ Responses (\%) } \\
\hline Variable & Very good & Good & Fair & Poor \\
\hline Self-rated health & 37.2 & 43.1 & 13.6 & 6.1 \\
\hline Environmental quality & Very serious & Somewhat serious & Not very serious & Not at all serious \\
\hline Poor water quality & 56.1 & 19.9 & 8.4 & 5.5 \\
\hline Poor air quality & 36.7 & 20.4 & 29.4 & 12.9 \\
\hline Poor sewage and sanitation & 55.2 & 22.8 & 16.4 & 5.1 \\
\hline
\end{tabular}

Source: 2007 WVS Ghana Results - Technical Record v.2015.04.18

Note: The rows do not all necessarily sum up to $100 \%$ due to responses in the "No answer", "Don’t know", etc. categories not reported here.

Table 3 reports the ordered probit regression results for the effect of perceived local environmental quality on self-rated health. Self-rated health is regressed on each local environmental problem while controlling for the socio-demographic variables discussed in section 3. Models I, II and III test the effect on self-rated health of poor water quality, poor air quality, and poor sewage and sanitation, respectively. ${ }^{3}$ Given the ratings on the health and environmental quality variables, a negative regression coefficient means that the more an individual perceives a particular environmental problem as serious, the more likely they were to rate their health status poorly. Each of the environmental problems had a negative and statistically significant effect on self-rated health.

The effect of poor water quality is highest and statistically significant at the 5\% level while poor air quality and poor sewage and sanitation were statistically significant at the $10 \%$ level. These results confirm prior findings that environmental quality significantly influences people's reporting of their health status (e.g., Kahlmeier, et al., 2001; Poortinga et al., 2007). If indeed people's evaluation of the environmental quality of their own community could reliably reflect the state of the environment in that, then it could be argued that these results suggest the poor nature of water, air, and sewage and sanitation quality in Ghana. Perhaps, people's understanding of the health ramifications of these environmental problems led them to rate their health accordingly. On the other hand, respondents in communities where these

\footnotetext{
${ }^{3}$ The partial correlations between the environmental quality variables ranged from 0.524 to 0.573 and are all statistically significant at the $1 \%$ level. Therefore, to avoid multicollinearity, each environmental problem variable was tested in a separate model.
} 
environmental problems are either not serious or non-existent at all reported better health.

Table. 3. Ordered probit regression results showing the effect of perceived environmental quality on self-rated health

\begin{tabular}{|c|c|c|c|}
\hline Variable & Model I & Model II & Model III \\
\hline Poor water quality & $\begin{array}{l}-0.079 * * \\
(0.0323)\end{array}$ & & \\
\hline Poor air quality & & $\begin{array}{l}-0.052 * \\
(0.028) \\
\end{array}$ & \\
\hline Poor sewer and sanitation & & & $\begin{array}{l}-0.062 * \\
(0.033)\end{array}$ \\
\hline Age & $\begin{array}{l}-0.018^{* * * *} \\
(0.002)\end{array}$ & $\begin{array}{l}-0.018^{* * * *} \\
(0.002)\end{array}$ & $\begin{array}{l}-0.018^{* * * *} \\
(0.002)\end{array}$ \\
\hline \multicolumn{4}{|l|}{ Gender $($ Ref = Male $)$} \\
\hline Female & $\begin{array}{l}-0.230 * * * \\
(0.062)\end{array}$ & $\begin{array}{l}-0.228^{* * *} \\
(0.062)\end{array}$ & $\begin{array}{l}-0.229 * * * \\
(0.062)\end{array}$ \\
\hline \multicolumn{4}{|c|}{ Education $($ Ref = Primary or less) } \\
\hline Secondary & $\begin{array}{l}0.031 \\
(0.072)\end{array}$ & $\begin{array}{l}0.040 \\
(0.072)\end{array}$ & $\begin{array}{l}0.037 \\
(0.072)\end{array}$ \\
\hline University & $\begin{array}{l}-0.163 \\
(0.139)\end{array}$ & $\begin{array}{l}-0.147 \\
(0.139)\end{array}$ & $\begin{array}{l}-0.152 \\
(0.139)\end{array}$ \\
\hline Unemployed & $\begin{array}{l}-0.211 * * * \\
(0.071)\end{array}$ & $\begin{array}{l}-0.209 * * * \\
(0.071)\end{array}$ & $\begin{array}{l}-0.208 * * * \\
(0.071)\end{array}$ \\
\hline Income scale & $\begin{array}{l}-0.084 * * * \\
(0.014)\end{array}$ & $\begin{array}{l}-0.083^{* * * *} \\
(0.014)\end{array}$ & $\begin{array}{l}-0.084 * * * \\
(0.014)\end{array}$ \\
\hline \multicolumn{4}{|c|}{ Marital status (Ref = Other marital status) } \\
\hline Married & $\begin{array}{l}0.015 \\
(0.070)\end{array}$ & $\begin{array}{l}0.019 \\
(0.070)\end{array}$ & $\begin{array}{l}0.015 \\
(0.070)\end{array}$ \\
\hline Divorced/separated & $\begin{array}{l}0.115 \\
(0.141)\end{array}$ & $\begin{array}{l}0.116 \\
(0.141)\end{array}$ & $\begin{array}{l}0.108 \\
(0.141)\end{array}$ \\
\hline \multicolumn{4}{|c|}{ Size of town $($ Ref $=$ Small town $)$} \\
\hline Mid-size town & $\begin{array}{l}0.043 \\
(0.083) \\
\end{array}$ & $\begin{array}{l}0.064 \\
(0.082)\end{array}$ & $\begin{array}{l}0.067 \\
(0.082) \\
\end{array}$ \\
\hline Large town & $\begin{array}{l}-0.007 \\
(0.077)\end{array}$ & $\begin{array}{l}0.012 \\
(0.077)\end{array}$ & $\begin{array}{l}0.004 \\
(0.077)\end{array}$ \\
\hline $\begin{array}{l}\text { Pseudo-R }{ }^{2} \\
\% \text { Correctly predicted } \\
\text { Likelihood Ratio }(\mathrm{df}=11)\end{array}$ & $\begin{array}{l}0.118 \\
64.00 \\
159.154 * * *\end{array}$ & $\begin{array}{l}0.116 \\
63.90 \\
156.426^{* * *}\end{array}$ & $\begin{array}{l}0.117 \\
64.00 \\
156.740 * * *\end{array}$ \\
\hline
\end{tabular}

Note: $\mathrm{N}=1406$. Standard errors are in parentheses. $* * *$ Significant at the $1 \%$ level. $* *$ Significant at the $5 \%$ level.

* Significant at the $10 \%$ level.

With regards to the control variables, the results indicate that older people and females were more likely to report poor health status. These findings confirm the results of prior studies 
(e.g., Rahman et al., 1994; McCullough \& Laurenceau, 2004; Addai \& Adjei, 2014). Education has no effect on self-rated health. Consistent with previous findings in the literature, the results here indicate that unemployment is negatively associated with self-rated health (Giatti et al., 2011; Carlier et al., 2013; Norström et al., 2014). In other words, the unemployed were more likely to report poor health. Beyond the effect of unemployment on self-rated health, Carlier et al. (2013) observed that re-employment significantly improves health status among previously unemployed people. As shown on Table 3, relative to respondents who were either widowed or single (never married), those who were either married or divorced or separated were not significantly different with respect to their health ratings. This finding that marital status has no significant impact on self-rated health corroborates results from previous studies (e.g., Kawada \& Suzuki, 2011; Addai \& Adjei, 2014). The results suggest that the size of town of residence of the respondent had no effect on their reporting of their health status.

\section{Summary and Conclusion}

The primary objective of this study was to examine the relationship between people's perceptions about the quality of their local environment in Ghana and their assessment of their own health. Consequently, the paper used data from the Wave 5 of the World Values Survey to empirically examine this relationship, focusing on the effect on self-rated health of poor water quality, poor air quality and poor sewage and sanitation. The results from ordered probit regressions revealed that each of these environmental quality measures is negatively and significantly correlated with self-rated health, implying that people who perceive these environmental problems as serious in their own community also tended to report poorly of their health status.

This study contributes to the literature on the relationship between environmental quality and health by adding further empirical evidence from a developing country perspective. One policy implication of the findings is that by improving environmental quality in Ghana, public policy could enhance public health. To the extent that re-employment of previously unemployed people can improve their health ratings (Carlier et al., 2013), another policy implication is that by boosting labor market outcomes, the government could also improve the general health of the people.

This study is not without limitations. One limitation pertains to the measure of self-rated health. Considering that this is based on survey data, a pertinent question is how respondents arrive at the responses they provide (see e.g., Mossey \& Shapiro, 1982; Crossley \& Kennedy, 2002). For instance, Crossley \& Kennedy (2002) studied the reliability of self-assessed health status in Australia by asking respondents to indicate their health status twice. They found that, after adding some health related questions, about $28 \%$ of respondents changed their self-rated health ranking from what they indicated prior to adding those additional health questions. Thus, some research into how individuals arrive at their rating of their health may be warranted.

Closely related to the above limitation is the idea that there might be some endogeneity in the data. Like many previous studies, this study has treated environmental quality as a cause and 
self-rated health as an effect. However, it could be that people's rating of their own health influences how they perceive the seriousness of various environmental problems. To illustrate, an individual who is suffering (or has ever suffered) from an environmentally related disease (e.g., malaria, cholera, etc.) may be more likely to exaggerate the seriousness of the poor nature of a given environmental issue in their community. It may also be that some other variables (e.g., psychological traits) influence the association between perceived environmental quality and self-rated health but which are not controlled for. Thus, further examination of the nature of the relationship between perceived environmental quality and self-rated health may be seemly. Finally, this study relies on the individual's perceptions of the quality of the environment in their community rather than on objective measures (see e.g., Poortinga et al., 2007).

\section{References}

Addai, I., \& Adjei, J. (2014). Predictors of self-appraised health status in sub-Saharan Africa: The case of Ghana. Applied Research in Quality of Life, 9(2), 233-253.

http://dx.doi.org/10.1007/s11482-013-9220-3.

Andreoni, J., \& Levinson, A. (2001). The simple analytics of the environmental Kuznets curve. Journal of Public Economics, 80(2), 269-286.

http://dx.doi.org/10.1016/S0047-2727(00)00110-9.

Affum, H. A., Oduro-Afriyie, K., Nartey, V. K., Adomako, D., \& Nyarko, B. B. (2008). Biomonitoring of airborne heavy metals along a major road in Accra, Ghana. Environmental Monitoring and Assessment, 137(1-3), 15-24. http://dx.doi.org/10.1007/s10661-007-9701-7.

Armah, F. A., Yawson, D. O., \& Pappoe, A. A. (2010). A systems dynamics approach to explore traffic congestion and air pollution link in the city of Accra, Ghana. Sustainability, 2(1), 252-265. http://dx.doi.org/10.3390/su2010252.

Azam, M. (2016). Does environmental degradation shackle economic growth? A panel data investigation on 11 Asian countries. Renewable and Sustainable Energy Reviews, 65, 175-182. http://dx.doi.org/10.1016/j.rser.2016.06.087.

Azam, M., Khan, A. Q., Abdullah, H. B., \& Qureshi, M. E. (2016). The impact of CO2 emissions on economic growth: evidence from selected higher CO2 emissions economies. Environmental Science and Pollution Research, 23(7), 6376-6389.

http://dx.doi.org/10.1007/s11356-015-5817-4.

Becker, W. E., \& Kennedy, P. E. (1992). A graphical exposition of the ordered probit. Econometric Theory, 8(01), 127-131. https://doi.org/10.1017/S0266466600010781.

Bethea, T. N., Lopez, R. P., Cozier, Y. C., White, L. F., \& McClean, M. D. (2012). The Relationship Between Rural Status, Individual Characteristics, and Self - Rated Health in the Behavioral Risk Factor Surveillance System. The Journal of Rural Health, 28(4), 327-338. http://dx.doi.org/10.1111/j.1748-0361.2012.00414.x.

Benyamini, Y., Blumstein, T., Lusky, A., \& Modan, B. (2003). Gender differences in the self-rated health-mortality association: Is it poor self-rated health that predicts mortality or 
excellent self-rated health that predicts survival? The Gerontologist, 43(3), 396-405. http://dx.doi.org/10.1093/geront/43.3.396.

Bruce, N., Perez-Padilla, R., \& Albalak, R. (2000). Indoor air pollution in developing countries: a major environmental and public health challenge. Bulletin of the World Health Organization, 78(9), 1078-1092. http://dx.doi.org/10.1590/S0042-96862000000900004.

Carlier, B. E., Schuring, M., Lötters, F. J., Bakker, B., Borgers, N., \& Burdorf, A. (2013). The influence of re-employment on quality of life and self-rated health, a longitudinal study among unemployed persons in the Netherlands. BMC Public Health, 13(1), 1-7. http://dx.doi.org/10.1186/1471-2458-13-503.

Carreras, H. A., \& Pignata, M. L. (2002). Biomonitoring of heavy metals and air quality in Cordoba City, Argentina, using transplanted lichens. Environmental Pollution, 117(1), 77-87. http://dx.doi.org/10.1016/S0269-7491(01)00164-6.

Cho, Y., Park, G. S., \& Echevarria-Cruz, S. (2005). Perceived neighborhood characteristics and the health of adult Koreans. Social Science \& Medicine, 60(6), 1285-1297. http://dx.doi.org/10.1016/j.socscimed.2004.06.054.

Collins, P. A., Hayes, M. V., \& Oliver, L. N. (2009). Neighbourhood quality and self-rated health: a survey of eight suburban neighbourhoods in the Vancouver Census Metropolitan Area. Health \& Place, 15(1), 156-164. http://dx.doi.org/10.1016/j.healthplace.2008.03.008.

Crossley, T. F., \& Kennedy, S. (2002). The reliability of self-assessed health status. Journal of Health Economics, 21(4), 643-658. http://dx.doi.org/10.1016/S0167-6296(02)00007-3.

Cummins, S., Stafford, M., Macintyre, S., Marmot, M., \& Ellaway, A. (2005). Neighbourhood environment and its association with self rated health: evidence from Scotland and England. Journal of Epidemiology and Community Health, 59(3), 207-213. http://dx.doi.org/10.1136/jech.2003.016147.

DeSalvo, K. B., Bloser, N., Reynolds, K., He, J., \& Muntner, P. (2006). Mortality prediction with a single general self - rated health question. Journal of General Internal Medicine, 21(3), 267-275. http://dx.doi.org/10.1111/j.1525-1497.2005.00291.x.

Do, D. P., \& Finch, B. K. (2008). The link between neighborhood poverty and health: context or composition? American Journal of Epidemiology, 168(6), 611-619.

http://dx.doi.org/10.1093/aje/kwn182.

Drabo, A. (2011). Impact of income inequality on health: does environment quality matter? Environment and Planning A, 43(1), 146-165. http://dx.doi.org/10.1068/a43307.

Fawell, J., \& Nieuwenhuijsen, M. J. (2003). Contaminants in drinking water environmental pollution and health. British Medical Bulletin, 68(1), 199-208.

http://dx.doi.org/10.1093/bmb/ldg027.

Fernandez-de-la-Hoz, K., \& León, D. A. (1996). Self-perceived health status and inequalities in use of health services in Spain. International Journal of Epidemiology, 25(3), 593-603. 
http://dx.doi.org/10.1093/ije/25.3.593.

Gadgil, A. (1998). Drinking water in developing countries. Annual Review of Energy and the Environment, 23(1), 253-286. http://dx.doi.org/10.1146/annurev.energy.23.1.253.

Ghana Health Service (2015). 2014 Annual Report. Ghana Health Service. Accra, Ghana. http://www.ghanahealthservice.org/downloads/Ghana_Health_Service_2014_Annual_Report. pdf (Accessed on November 14, 2016).

Giatti, L., Barreto, S., \& César, C. (2011). SP6-18 Unemployment and self rated health: neighbourhood influence? Journal of Epidemiology and Community Health, 65, A459-A460. http://dx.doi.org/10.1016/j.socscimed.2010.05.021.

Githeko, A., \& Woodward, A. (2003). International consensus on the science of climate and health: the IPCC Third Assessment Report. Climate Change and Human Health: Risks and Responses, 43-60.

Grossman, G. M., \& Krueger, A. B. (1991). Environmental impacts of a North American Free Trade Agreement. National Bureau of Economic Research Working Paper 3914, NBER, Cambridge MA. http://dx.doi.org/10.3386/w3914.

Heistaro, S., Jousilahti, P., Lahelma, E., Vartiainen, E., \& Puska, P. (2001). Self rated health and mortality: a long term prospective study in eastern Finland. Journal of Epidemiology and Community Health, 55(4), 227-232. http://dx.doi.org/10.1136/jech.55.4.227.

Hill, T. D., \& Needham, B. L. (2006). Gender-specific trends in educational attainment and self-rated health, 1972-2002. American Journal of Public Health, 96(7), 1288-1292. http://dx.doi.org/10.2105/AJPH.2004.061119.

Idler, E. L., \& Benyamini, Y. (1997). Self-rated health and mortality: a review of twenty-seven community studies. Journal of Health and Social Behavior, 38(1), 21-37. URL: http://www.jstor.org/stable/2955359.

Joutsenniemi, K. E., Martelin, T. P., Koskinen, S. V., Martikainen, P. T., Härkänen, T. T., Luoto, R. M., \& Aromaa, A. J. (2006). Official marital status, cohabiting, and self-rated health-time trends in Finland, 1978-2001. The European Journal of Public Health, 16(5), 476-483. http://dx.doi.org/10.1093/eurpub/cki221.

Kahlmeier, S., Schindler, C., Grize, L., \& Braun-Fahrländer, C. (2001). Perceived environmental housing quality and wellbeing of movers. Journal of Epidemiology and Community Health, 55(10), 708-715. http://dx.doi.org/10.1136/jech.55.10.708.

Kampa, M., \& Castanas, E. (2008). Human health effects of air pollution. Environmental Pollution, 151(2), 362-367. http://dx.doi.org/10.1016/j.envpol.2007.06.012.

Kawada, T., \& Suzuki, S. (2011). Marital status and self-rated health in rural inhabitants in Japan: a cross-sectional study. Journal of Divorce \& Remarriage, 52(1), 48-54. http://dx.doi.org/10.1080/10502556.2011.534395.

Kennedy, B. P., Kawachi, I., Glass, R., \& Prothrow-Stith, D. (1998). Income distribution, 
socioeconomic status, and self rated health in the United States: multilevel analysis. $B M J$, 317(7163), 917-921. doi: http://dx.doi.org/10.1136/bmj.317.7163.917.

KuÈnzli, N., Kaiser, R., Medina, S., Studnicka, M., Chanel, O., Filliger, P., .. \& Sommer, H. (2000). Public-health impact of outdoor and traffic-related air pollution: a European assessment. The Lancet, 356(9232), 795-801.

http://dx.doi.org/10.1016/S0140-6736(00)02653-2.

Lee, J. A., Park, J. H., \& Kim, M. (2015). Social and physical environments and self-rated health in urban and rural communities in Korea. International Journal of Environmental

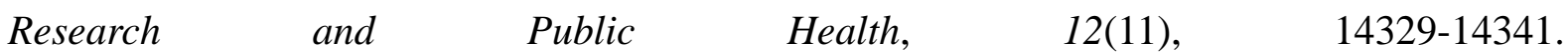
http://dx.doi.org/10.3390/ijerph121114329.

Liu, H. (2012). Marital dissolution and self-rated health: Age trajectories and birth cohort variations. Social Science \& Medicine, 74(7), 1107-1116.

http://dx.doi.org/10.1016/j.socscimed.2011.11.037.

McCullough, M. E., \& Laurenceau, J. P. (2004). Gender and the natural history of self-rated health: a 59-year longitudinal study. Health Psychology, 23(6), 651.

http://dx.doi.org/10.1037/0278-6133.23.6.651.

McKelvey, R. D., \& Zavoina, W. (1975). A statistical model for the analysis of ordinal level dependent variables. Journal of Mathematical Sociology, 4(1), 103-120. http://dx.doi.org/10.1080/0022250X.1975.9989847.

Mitchell, R., \& Popham, F. (2008). Effect of exposure to natural environment on health inequalities: an observational population study. The Lancet, 372(9650), 1655-1660. http://dx.doi.org/10.1016/S0140-6736(08)61689-X.

Monnat, S. M., \& Pickett, C. B. (2011). Rural/urban differences in self-rated health: Examining the roles of county size and metropolitan adjacency. Health \& Place, 17(1), 311-319. http://dx.doi.org/10.1016/j.healthplace.2010.11.008.

Mossey, J. M., \& Shapiro, E. (1982). Self-rated health: a predictor of mortality among the elderly. American Journal of Public Health, 72(8), 800-808.

http://dx.doi.org/10.2105/AJPH.72.8.800.

Mouchet, J., Manguin, S., Sircoulon, J., Laventure, S., Faye, O., Onapa, A., ... \& Fontenille, D. (1998). Evolution of malaria in Africa for the past 40 years: impact of climatic and human factors. Journal of the American Mosquito Control Association, 14(2), 121-130.

Mulsant, B. H., Ganguli, M., \& Seaberg, E. C. (1997). The relationship between self-rated health and depressive symptoms in an epidemiological sample of community-dwelling older adults. Journal of American Geriatric Society, 45, 954-958.

http://dx.doi.org/10.1111/j.1532-5415.1997.tb02966.x.

Neidell, M. J. (2004). Air pollution, health, and socio-economic status: the effect of outdoor air quality on childhood asthma. Journal of Health Economics, 23(6), 1209-1236. http://dx.doi.org/10.1016/j.jhealeco.2004.05.002. 
Nielsen, T. S., \& Hansen, K. B. (2007). Do green areas affect health? Results from a Danish survey on the use of green areas and health indicators. Health \& place, 13(4), 839-850. http://dx.doi.org/10.1016/j.healthplace.2007.02.001.

Norström, F., Virtanen, P., Hammarström, A., Gustafsson, P. E., \& Janlert, U. (2014). How does unemployment affect self-assessed health? A systematic review focusing on subgroup effects. BMC Public Health, 14(1), 1-13. http://dx.doi.org/10.1186/1471-2458-14-1310.

Poortinga, W., Dunstan, F. D., \& Fone, D. L. (2007). Perceptions of the neighbourhood environment and self rated health: a multilevel analysis of the Caerphilly Health and Social Needs Study. BMC Public Health, 7:285. http://dx.doi.org/10.1186/1471-2458-7-285.

Pope III, C. A., Bates, D. V., \& Raizenne, M. E. (1995). Health effects of particulate air pollution: time for reassessment? Environmental Health Perspectives, 103(5), 472-480.

Pope III, C. A., \& Dockery, D. W. (1992). Acute health effects of PM10 pollution on symptomatic and asymptomatic children. American Review of Respiratory Disease, 145(5), 1123-1128. http://dx.doi.org/10.1164/ajrccm/145.5.1123.

Rahman, O., Strauss, J., Gertler, P., Ashley, D., \& Fox, K. (1994). Gender differences in adult health: an international comparison. The Gerontologist, 34(4), 463-469.

http://dx.doi.org/10.1093/geront/34.4.463.

Ravindra, K., Mittal, A. K., \& Van Grieken, R. (2001). Health risk assessment of urban suspended particulate matter with special reference to polycyclic aromatic hydrocarbons: a review. Reviews on Environmental Health, 16(3), 169-189.

http://dx.doi.org/10.1515/REVEH.2001.16.3.169.

Ross, C. E., \& Mirowsky, J. (2001). Neighborhood disadvantage, disorder, and health. Journal of Health and Social Behavior, 42(3), 258-276. http://www.jstor.org/stable/3090214.

Ross, C. E., \& Wu, C. L. (1996). Education, age, and the cumulative advantage in health. Journal of Health and Social Behavior, 37(1), 104-120. http://www.jstor.org/stable/2137234.

Shafik, N., \& Bandyopadhyay, S. (1992). Economic Growth and Environmental Quality: Time Series and Cross-Country Evidence. Policy Research Working Paper No. WPS 904. Washington, D. C. The World Bank.

Shibuya, K., Hashimoto, H., \& Yano, E. (2002). Individual income, income distribution, and self rated health in Japan: cross sectional analysis of nationally representative sample. $B M J$, 324(7328), 16, 1-5. http://dx.doi.org/10.1136/bmj.324.7328.16.

Shier, R. P., Dollimore, N., Ross, D. A., Binka, F. N., Quigley, M., \& Smith, P. G. (1996). Drinking water sources, mortality and diarrhea morbidity among young children in Northern Ghana. Tropical Medicine \& International Health, 1(3), 334-341.

http://dx.doi.org/10.1046/j.1365-3156.1996.d01-55.x.

Stern, D. I. (2004). The Rise and Fall of the Environmental Kuznets Curve. World Development, 32(8), 1419-1439. http://dx.doi.org/10.1016/j.worlddev.2004.03.004. 


\section{Macrothink}

Stronegger, W. J., Titze, S., \& Oja, P. (2010). Perceived characteristics of the neighborhood and its association with physical activity behavior and self-rated health. Health \& Place, 16(4), 736-743. http://dx.doi.org/10.1016/j.healthplace.2010.03.005.

Sulemana, I. (2012). Assessing Over-aged Car Legislation as an Environmental Policy Law in Ghana. International Journal of Business and Social Science, 3(20), 57-64.

Sulemana, I., James, H. S., \& Valdivia, C. B. (2016a). Perceived socioeconomic status as a predictor of environmental concern in African and developed countries. Journal of Environmental Psychology, 46, 83-95. http://dx.doi.org/10.1016/j.jenvp.2016.04.002.

Sulemana, I., McCann, L., \& James Jr, H. S. (2016b). Perceived environmental quality and subjective well-being: are African countries different from developed countries? International Journal of Happiness and Development, 3(1), 64-87.

http://dx.doi.org/10.1504/IJHD.2016.076209.

Sulemana, I., James, H. S., \& Rikoon, J. S. (2016c). Environmental Kuznets Curves for air pollution in African and developed countries: exploring turning point incomes and the role of democracy. Journal of Environmental Economics and Policy, Forthcoming.

http://dx.doi.org/10.1080/21606544.2016.1231635.

Tayeh, A., Cairncross, S., \& Maude, G. H. (1993). Water sources and other determinants of dracunculiasis in the Northern Region of Ghana. Journal of Helminthology, 67(03), 213-225. http://dx.doi.org/10.1017/S0022149X00013158.

United Nations (2014). The Millennium Development Goals Report. New York, United Nations.

World Health Organization (2015). World Malaria Report 2015. Geneva, Switzerland. http://apps.who.int/iris/bitstream/10665/200018/1/9789241565158_eng.pdf. (Accessed November 14, 2016).

Wu, S., Wang, R., Zhao, Y., Ma, X., Wu, M., Yan, X., \& He, J. (2013). The relationship between self-rated health and objective health status: a population-based study. BMC Public Health, 13(1), 1-9. http://dx.doi.org/10.1186/1471-2458-13-320.

\section{Copyright Disclaimer}

Copyright for this article is retained by the author(s), with first publication rights granted to the journal.

This is an open-access article distributed under the terms and conditions of the Creative Commons Attribution license (http://creativecommons.org/licenses/by/3.0/). 